\title{
Modelling future changes to the stratospheric source gas injection of biogenic bromocarbons
}

\author{
R. Hossaini, ${ }^{1}$ M. P. Chipperfield, ${ }^{1}$ S. Dhomse, ${ }^{1}$ C. Ordóñez, ${ }^{2}$ A. Saiz-Lopez, ${ }^{2}$ \\ N. L. Abraham, ${ }^{3,4}$ A. Archibald, ${ }^{3,4}$ P. Braesicke, ${ }^{3,4}$ P. Telford, ${ }^{3,4}$ N. Warwick, ${ }^{3,4}$ \\ X. Yang, ${ }^{3,4}$ and J. Pyle ${ }^{3,4}$
}

Received 31 July 2012; revised 27 September 2012; accepted 2 October 2012; published 30 October 2012.

[1] Simulations with a chemistry-climate model (CCM) show a future increase in the stratospheric source gas injection (SGI) of biogenic very short-lived substances (VSLS). For 2000, the modelled SGI of bromine from VSLS is $\sim 1.7$ parts per trillion (pptv) and largest over the tropical West Pacific. For 2100 , this increases to $\sim 2.0$ and $\sim 2.7 \mathrm{pptv}$ when the model is forced with Intergovernmental Panel on Climate Change (IPCC) representative concentration pathways (RCPs) 4.5 and 8.5 . The increase is largely due to stronger tropical deep convection transporting more $\mathrm{CHBr}_{3}$ to the lower stratosphere. For $\mathrm{CH}_{2} \mathrm{Br}_{2}, \mathrm{CHBr}_{2} \mathrm{Cl}, \mathrm{CH}_{2} \mathrm{BrCl}$ and $\mathrm{CHBrCl}_{2}$, changes to primary oxidant $\mathrm{OH}$ determines their SGI contribution. Under RCP 4.5 (moderate warming), $\mathrm{OH}$ increases in a warmer, more humid troposphere. Under RCP 8.5 (extreme warming) $\mathrm{OH}$ decreases significantly due to a large methane increase, allowing greater SGI of bromine from these VSLS. Potentially enhanced VSLS emissions in the future would further increase these estimates. Citation: Hossaini, R., et al. (2012), Modelling future changes to the stratospheric source gas injection of biogenic bromocarbons, Geophys. Res. Lett., 39, L20813, doi:10.1029/2012GL053401.

\section{Introduction}

[2] The importance of active bromine radicals $\left(\mathrm{Br}_{x}=\mathrm{Br}+\right.$ $\mathrm{BrO})$ in the catalytic destruction of stratospheric ozone $\left(\mathrm{O}_{3}\right)$ is well established [Wofsy et al., 1975]. Due to a lack of stable reservoirs, $\mathrm{BrO}$ is the dominant inorganic bromine $\left(\mathrm{Br}_{y}\right)$ species in the stratosphere. Coupled cycles, involving analogous chlorine radicals, account for a significant total of seasonal $\mathrm{O}_{3}$ loss observed over Antarctica [Montzka et al., 2011]. At mid-latitudes, the BrO-ClO cycle is enhanced during periods of high aerosol loading due to heterogeneous halogen activation. The coupled $\mathrm{BrO}-\mathrm{HO}_{2}$ cycle is important for $\mathrm{O}_{3}$ loss in the mid-latitude lower stratosphere [Salawitch et al., 2005]. On a per-atom basis, bromine is a factor of $\sim 60$ more efficient than chlorine as an $\mathrm{O}_{3}$ sink in the lower

\footnotetext{
${ }^{1}$ Institute for Climate and Atmospheric Science, School of Earth and Environment, University of Leeds, Leeds, UK.

${ }^{2}$ Laboratory for Atmospheric and Climate Science, CSIC, Toledo, Spain.

${ }^{3}$ National Centre for Atmospheric Science, Cambridge, UK.

${ }^{4}$ Department of Chemistry, University of Cambridge, Cambridge, UK.

Corresponding author: R. Hossaini, Institute for Climate and Atmospheric Science, School of Earth and Environment, University of Leeds, Leeds LS2 9JT, UK. (r.hossaini@see.leeds.ac.uk)

C2012. American Geophysical Union. All Rights Reserved. 0094-8276/12/2012GL053401
}

stratosphere [Sinnhuber et al., 2009]. Changes to stratospheric $\mathrm{O}_{3}$ can impact surface temperature and climate.

[3] The dominant sources of stratospheric $\mathrm{Br}_{y}$ are the long-lived gases, methyl bromide $\left(\mathrm{CH}_{3} \mathrm{Br}\right)$ and halons (e.g. Halon $1211, \mathrm{CF}_{2} \mathrm{ClBr}$ ). Emissions of the former are largely of natural origin $(\sim 65 \%)$, while halons, which were used as fire suppressants, are exclusively anthropogenic. As production is regulated under the Montreal Protocol, their abundance is expected to decline significantly in coming decades [Montzka et al., 2003]. It is also known that very short-lived substances (VSLS), primarily emitted from macroalgae and plankton [e.g., Quack and Wallace, 2003], may also reach the stratosphere [e.g., Sturges et al., 2000]. Their contribution to stratospheric $\mathrm{Br}_{y}\left(\mathrm{Br}_{y}^{V S L S}\right)$ is estimated to be 1-8 pptv [Montzka et al., 2011].

[4] The most abundant brominated VSLS are bromoform $\left(\mathrm{CHBr}_{3}\right)$ and dibromomethane $\left(\mathrm{CH}_{2} \mathrm{Br}_{2}\right)$. Average marine boundary layer (MBL) mixing ratios are $\sim 1.1$ and $1.5 \mathrm{pptv}$ [Montzka et al., 2011]. The surface lifetime of a VSLS is less than 6 months. However, once transported to the upper troposphere, lifetimes may be considerably longer [Hossaini et al., 2010]. Strong convective regions such as the tropical West Pacific are important for the troposphere-to-stratosphere transport of VSLS [Aschmann et al., 2009].

[5] There have been suggestions that $\mathrm{Br}_{y}^{V S L S}$ may increase in a future climate [e.g., Pyle et al., 2007]. Dessens et al. [2009] found dynamical changes due to global warming will likely enhance troposphere-to-stratosphere transport of VSLS. However, they did not explicitly model future changes to primary oxidant $\mathrm{OH}$ and thus the impact of a perturbed oxidizing capacity on the stratospheric flux of VSLS remains unclear. Understanding these processes is required to assess the role of (biogenic) bromine on the future evolution/recovery of stratospheric $\mathrm{O}_{3}$. In this paper we quantify changes to the entrainment of brominated VSL source gases into the lower stratosphere under projected 2100 climates. The relative influence of changes to the tropospheric oxidizing capacity and tropospheric transport are examined. The impact of VSLS on stratospheric $\mathrm{O}_{3}$ is not examined here.

\section{Model and Experiments}

[6] The United Kingdom Chemistry and Aerosols (UKCA) CCM is based on the dynamical core of the Met Office Unified Model (UM) version 7.3. The model recently took part in the Stratospheric Processes and their Role in Climate (SPARC) Chemistry-Climate Model Validation Activity [Erying et al., 2010]. UKCA contains detailed stratospheric chemistry and photolysis rates are computed online using the FAST-JX scheme [Morgenstern et al., 
Table 1. Prescribed Surface Volume Mixing Ratio of Key Greenhouse Gases and Long-Lived Bromocarbons

\begin{tabular}{lcccccccc}
\hline Experiment & $\mathrm{CO}_{2}(\mathrm{ppm})$ & $\mathrm{CH}_{4}(\mathrm{ppb})$ & $\mathrm{N}_{2} \mathrm{O}(\mathrm{ppb})$ & $\mathrm{H}-1211(\mathrm{ppt})$ & $\mathrm{H}-1202(\mathrm{ppt})$ & $\mathrm{H}-1301(\mathrm{ppt})$ & $\mathrm{H}-2402(\mathrm{ppt})$ & $\mathrm{CH} \mathrm{Br}_{3}(\mathrm{ppt})$ \\
\hline$S-2000$ & 370 & 1765 & 316 & 4.04 & 0.05 & 2.73 & 0.41 & 8.66 \\
$S-R C P 4.5$ & 538 & 1577 & 372 & 0.05 & $<0.01$ & 0.98 & $<0.01$ & 6.40 \\
$S-R C P 8.5$ & 935 & 3750 & 435 & 0.04 & $<0.01$ & 0.78 & $<0.01$ & 5.70 \\
\hline
\end{tabular}

2009]. The following gases are interactive with radiation [Edwards and Slingo, 1996]: $\mathrm{O}_{3}$, carbon dioxide $\left(\mathrm{CO}_{2}\right)$, methane $\left(\mathrm{CH}_{4}\right)$, nitrous oxide $\left(\mathrm{N}_{2} \mathrm{O}\right)$, chlorofluorocarbons (CFCs) and hydrochlorofluorocarbons.

[7] UKCA was run with a horizontal resolution of $3.75^{\circ}$ longitude $\times 2.5^{\circ}$ latitude and with 60 hybrid-height levels (surface to $\sim 80 \mathrm{~km}$ ). Three 20 -year time slice experiments were performed in atmosphere-only mode, corresponding to 2000 and 2100 conditions; S-2000, S-RCP4.5 and SRCP8.5. For 2000, UKCA was forced with prescribed monthly mean fields of sea surface temperature (SST) and sea ice [Rayner et al., 2003]. For 2100, output of the HadGEM2-CCS climate model [Martin et al., 2011] was used for these fields. For 2000, greenhouse gas (GHG) loading and long-lived halocarbons (e.g. halons, CFCs), were prescribed according to the WMO A1 scenario [Montzka et al., 2011]. For 2100 experiments (S-RCP4.5 and S-RCP8.5) these gases were constrained by IPCC RCP 4.5 and 8.5 [van Vuuren et al., 2011] (see Table 1). These scenarios span moderate to extreme climate change resulting in a projected surface warming in the region of $\sim 2.0 \mathrm{~K}$ and $\sim 4.0 \mathrm{~K}$ by 2100 , respectively.

[8] In this study, five biogenic VSLS tracers were added to UKCA. For major VSLS CHBr ${ }_{3}$ and $\mathrm{CH}_{2} \mathrm{Br}_{2}$, the monthlyvarying emission estimates of Ordónez et al. [2012] were used for both 2000 and 2100 experiments. Their global source strengths are $533 \mathrm{Gg} \mathrm{yr}^{-1}$ and $67.3 \mathrm{Gg} \mathrm{yr}^{-1}$. For minor (and relatively long-lived) $\mathrm{VSLS} \mathrm{CHBr} 2 \mathrm{Cl}, \mathrm{CHBrCl}_{2}$ and $\mathrm{CH}_{2} \mathrm{BrCl}$, a prescribed mixing ratio $(0.3,0.3$ and $0.5 \mathrm{pptv})$, based on observations in the MBL [Montzka et al., 2011], was used to constrain their surface abundance. This model set up has been evaluated extensively with ground-based and aircraft observations.

\section{Results and Discussion}

[9] Aircraft observations suggest $0.09(0.0-0.31) \mathrm{pptv}$ of $\mathrm{CHBr}_{3}$ at the tropical $\left( \pm 20^{\circ}\right.$ latitude) tropopause (TT, $\sim 17 \mathrm{~km}$ ) [Montzka et al., 2011]. In this region, UKCA is able to reproduce observed mixing ratios of major VSLS (see auxiliary material). ${ }^{1}$ The modelled 2000 zonally averaged TT abundance of $\mathrm{CHBr}_{3}$ is $\sim 0.1 \mathrm{pptv}$. For 2100, this estimate increases to $0.2 \mathrm{pptv}$ under RCP 4.5 , and significantly to $0.36 \mathrm{pptv}$, under RCP 8.5 . The local increase is largest over the West Pacific during northern hemisphere winter (DJF, Figure 1), when transport through the TTL is most rapid [Fueglistaler et al., 2005]. Here the modelled $\mathrm{CHBr}_{3}$ increase peaks at $\sim 0.7 \mathrm{pptv}$ (i.e. $2.1 \mathrm{pptv}$ more of bromine).

[10] SGI refers to the transport of organic VSLS to the stratosphere where, on degradation, they release in-situ $\mathrm{Br}_{y}^{V S L S}$. Efficient SGI requires troposphere-to-stratosphere transport to be on timescales comparable to, or shorter than,

${ }^{1}$ Auxiliary materials are available in the HTML. doi:10.1029/ 2012GL053401. tropospheric loss rates. $\mathrm{CHBr}_{3}$, which may account for $\sim 35 \%$ of the total SGI from VSLS [Hossaini et al., 2012], has a surface lifetime of $\sim 24$ days and its primary tropospheric sink is photolysis. As the shortest lived gas considered here, its abundance in the lower stratosphere is most sensitive to changes to the tropospheric circulation, particularly in the tropics where emissions are large.

[11] The modelled 2100 convective updraft mass flux mostly decreases in the tropical lower and mid-troposphere (see auxiliary material). In the upper troposphere (UT, $\sim 12$ $17 \mathrm{~km}$ ), the change is positive with large increases over the Western Pacific (Figure 2a), where strong convection is sustained to higher altitudes. The prevalence of deep convection, important for the transport of VSLS to the UT, may increase in response to global warming [e.g., Chou and Chen, 2010]. The results here are consistent with Stevenson et al. [2005] and Dessens et al. [2009] who also show an increase in the updraft strength in the UT. Age-of-air, here defined as the mean time since a parcel was in contact with the surface, is reduced (Figure $2 \mathrm{~b}$ ). This reduction reflects change to both large-scale and convective-scale motions and correlates with enhanced $\mathrm{CHBr}_{3}$ at $17 \mathrm{~km}$ (Figure 2c).

[12] For $\mathrm{CH}_{2} \mathrm{BrCl}, \mathrm{CH}_{2} \mathrm{Br}_{2}$ (Figure 2d), $\mathrm{CHBrCl}_{2}$ and $\mathrm{CHBr}_{2} \mathrm{Cl}$, whose surface lifetimes (137, 123, 78 and 59 days) are considerably longer [Montzka et al., 2011], perturbations to tropospheric transport time-scales have a significant,

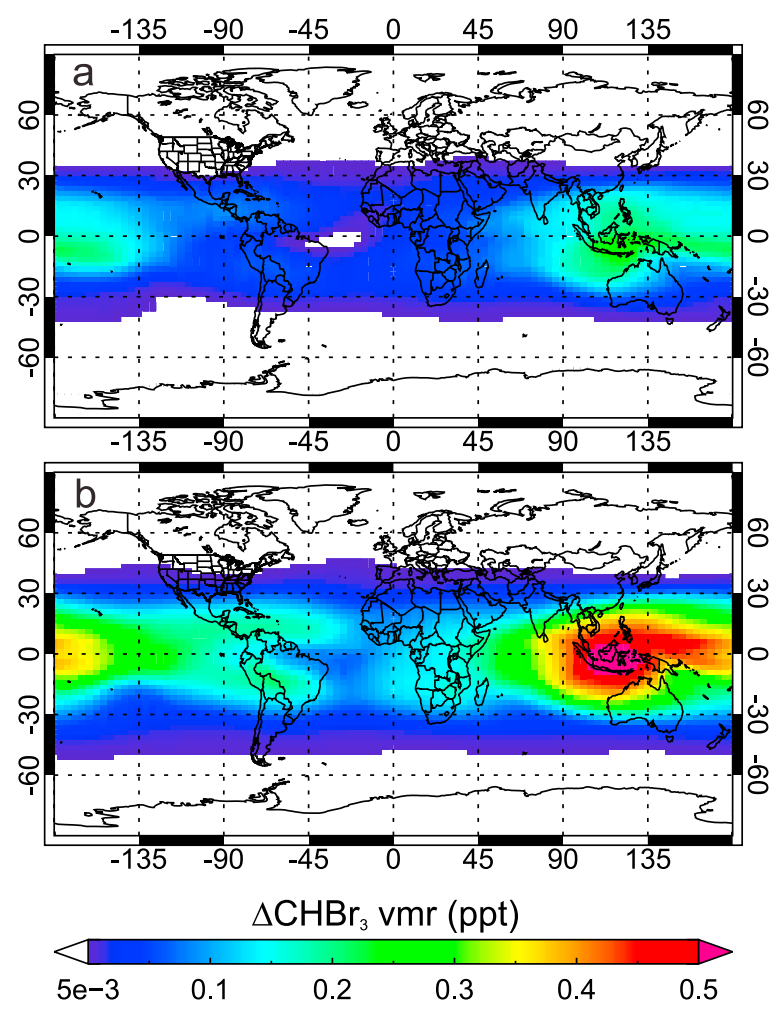

Figure 1. DJF mean increase in $\mathrm{CHBr}_{3}$ volume mixing ratio (pptv) at $\sim 17 \mathrm{~km}$ for (a) RCP 4.5 and (b) RCP 8.5 . 
(a) Updraft mass flux

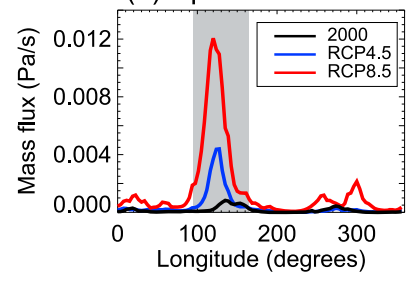

(b) Age of air

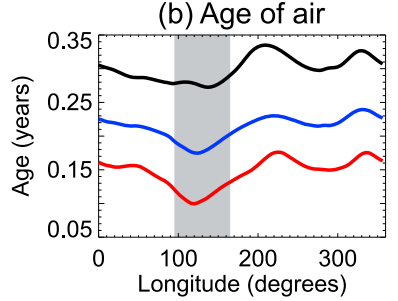

(c) $\mathrm{CHBr}_{3}$

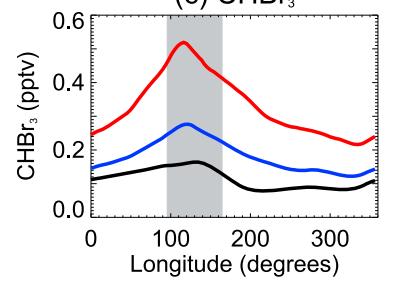

(d) $\mathrm{CH}_{2} \mathrm{Br}_{2}$

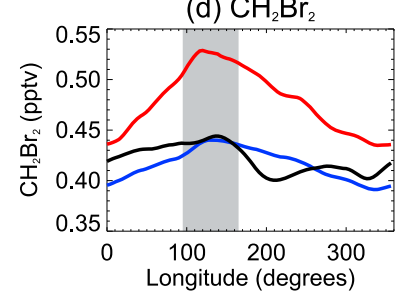

Figure 2. Longitudinal dependence of (a) convective updraft mass flux (Pa/s), (b) age-of-air (years), (c) $\mathrm{CHBr}_{3}$ (pptv) and (d) $\mathrm{CH}_{2} \mathrm{Br}_{2}$ (pptv) averaged over the tropics $\left( \pm 20^{\circ}\right)$ at $\sim 17 \mathrm{~km}$ for 2000 and 2100 experiments. The West Pacific region (95-165 longitude) is shaded.

yet smaller impact on their abundance in the lower stratosphere. Rather, these less photolabile gases are more sensitive to changes to primary oxidant $\mathrm{OH}$.

[13] Figure 3a shows the modelled 2100 change in [OH] with respect to (w.r.t.) 2000. Warmer lower atmospheric temperature leads to enhanced water vapour and thus enhanced $\mathrm{OH}$ production through the $\mathrm{H}_{2} \mathrm{O}+\mathrm{O}\left({ }^{1} D\right)$ channel. Under RCP 4.5, [OH] increases throughout the troposphere, with a peak mean increase of $\sim 0.2 \times 10^{6}$ molecules $\mathrm{cm}^{-3}$ (15\% increase w.r.t. 2000 ) occurring at $\sim 15 \mathrm{~km}$. Zeng et al. [2008] show a similar response for a $2100 \mathrm{CCM}$ experiment in which $\left[\mathrm{CO}_{2}\right]$ was doubled. Due to difference in experimental set up, a direct comparison of results is not appropriate. However, qualitatively, increased tropospheric [OH] is consistent between models and is of a similar magnitude.

[14] However for RCP 8.5, despite enhanced water vapour, below $\sim 10 \mathrm{~km}$ the $[\mathrm{OH}]$ response is negative. Between RCPs there is large variation in $\left[\mathrm{CH}_{4}\right]$ (Table 1). Under RCP 4.5, a scenario where GHG emissions are mitigated, $2100 \mathrm{CH}_{4}$ is $\sim 10 \%$ lower w.r.t. 2000. Conversely, under RCP 8.5, a non-mitigation scenario, it increases by $\sim 112 \%$. Enhanced $\mathrm{CH}_{4}$ tends to decrease [OH] [e.g., Wuebbles et al., 1989] and has a positive feedback on its own lifetime. The rate of the $\mathrm{CH}_{4}+\mathrm{OH}$ reaction has a strong

temperature-dependence and increases with the large increase in tropospheric temperature under RCP 8.5 (>4.5 K at the surface).

[15] Changes to the tropospheric oxidizing capacity have a small impact on $\mathrm{CHBr}_{3}$. Although, enhanced [OH] under RCP 4.5 reduces the $\mathrm{CHBr}_{3}$ lifetime, particularly near the surface, where oxidation by $\mathrm{OH}$ can compete with the faster photolysis sink [Hossaini et al., 2010]. However, overall the $\mathrm{CHBr}_{3}$ change w.r.t. 2000 (Figure 3b) is small. Under RCP 8.5 , the dominant process is the significant increase in the strength of deep tropical convection which enables more $\mathrm{CHBr}_{3}$ to reach the upper troposphere-lower stratosphere (UTLS) (See Figure 2 also).

[16] For $\mathrm{CH}_{2} \mathrm{Br}_{2}$, under RCP 4.5 the change w.r.t. 2000 (Figure $3 \mathrm{c}$ ) closely follows $\Delta[\mathrm{OH}]$. Its tropospheric lifetime is reduced due to enhanced $[\mathrm{OH}]$ and the positive temperature-dependence of the oxidation. For RCP 8.5, the situation is more complex. The $\mathrm{CH}_{2} \mathrm{Br}_{2}$ lifetime is extended near the surface (due to decreased $[\mathrm{OH}]$ ). However, the significantly warmer surface temperature compensates by speeding up the $\mathrm{OH}$ sink reaction and overall resulting in little change below $10 \mathrm{~km}$. In the upper troposphere, where this sink is significantly slower, the enhanced convective mass flux dominates by transporting more tracer to the UTLS region.

[17] Overall, the total SGI from brominated-VSLS increases from a zonally averaged 1.7 pptv (2000) to 2.0 pptv (2100, RCP 4.5) and 2.7 pptv (2100, RCP 8.5). Our experiments have assumed 2100 VSLS emissions are the same as present day. It is currently unknown if and how emissions may change in response to climate or other forcings. However, an increase in the tropical MBL abundance of VSLS due to changes to primary production, sea-air fluxes, landuse practice or indeed any other factors, would likely increase the SGI estimates reported here. The use of climatological SSTs in this study means variability associated with the El Niño-Southern Oscillation (ENSO) is not captured. The so-called product gas injection pathway (PGI), which is significantly more uncertain at present, has not been considered here but will be the subject of future work.

\section{Concluding Remarks}

[18] The stratospheric source gas injection of VSLS will likely increase in response to climate change. The magnitude of this increase will be determined by competing chemical and dynamical factors. For relatively short-lived gases such as bromoform, whose primary tropospheric sink is photolysis, and therefore subject to relatively minor
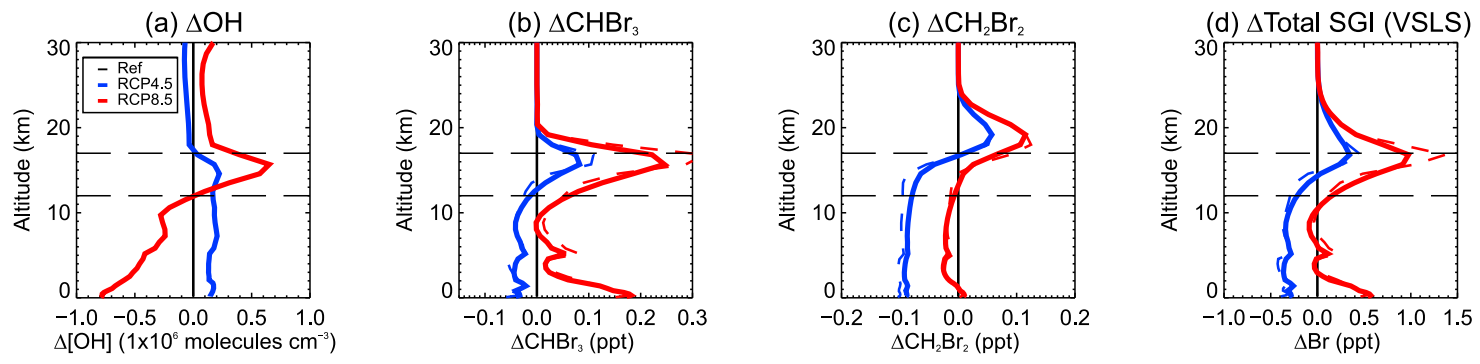

Figure 3. 2100 annual zonal mean change w.r.t. 2000 of (a) $\mathrm{OH}$, (b) $\mathrm{CHBr}_{3}$, (c) $\mathrm{CH}_{2} \mathrm{Br}_{2}$ and (d) total SGI from all VSLS in the tropics $\left( \pm 20^{\circ}\right)$. Upper and lower dashed lines denotes the cold point tropopause and the approximate base of the tropical tropopause layer, respectively. Dashed profiles represent mean over the tropical Western Pacific region ( $90-165^{\circ}$ longitude). 
change, enhanced convection in 2100 leads to an increase in their lower stratospheric abundance. For dibromomethane, and other VSLS whose primary tropospheric sink is through oxidation, their abundance is highly sensitive to changes to the hydroxyl radical. For IPCC RCP 4.5 and RCP 8.5 , the tropospheric oxidizing capacity may differ significantly and more work is required to best constrain such changes.

[19] As for 2000, based on our CCM results, the tropical West Pacific will continue to be an efficient source region for the future transport of VSLS to the stratosphere. Changes to regional land use and practice, such as seaweed farming, which is currently a growing sector, could potentially significantly increase the surface loading of VSLS. This would likely increase the loading of VSLS into the stratosphere, particularly under a significantly warmer climate such as that of the IPCC RCP 8.5 projection.

[20] To assess the significance of VSLS on future global stratospheric ozone, further work is required to 1). determine potential changes to VSLS emission rates and 2). determine the efficiency of $\mathrm{Br}_{x} \mathrm{O}_{3}$ loss cycles under evolving stratospheric composition (e.g. decreasing chlorine, and potentially increasing hydrogen oxides).

[21] Acknowledgments. This work was supported by the UK NERC and the EU SHIVA project (SHIVA-226224-FP7-ENV-2008-1). We also thank Mohit Dalvi (Met Office) and NCAS-CMS for UM support.

[22] The Editor thanks two anonymous reviewers for assistance evaluating this paper.

\section{References}

Aschmann, J., B. M. Sinnhuber, E. L. Atlas, and S. M. Schauffler (2009), Modeling the transport of very short-lived substances into the tropical upper troposphere and lower stratosphere, Atmos. Chem. Phys., 9(23), 9237-9247.

Chou, C., and C.-A. Chen (2010), Depth of convection and the weakening of tropical circulation in global warming, J. Clim., 23(11), 3019-3030, doi:10.1175/2010JCLI3383.1.

Dessens, O., G. Zeng, N. Warwick, and J. Pyle (2009), Short-lived bromine compounds in the lower stratosphere; impact of climate change on ozone, Atmos. Sci. Lett., 10(3), 201-206, doi:10.1002/asl.236.

Edwards, J., and A. Slingo (1996), Studies with a flexible new radiation code. I: Choosing a configuration for a large-scale model, $Q$. J. R. Meteorol. Soc., 122(531), 689-719, doi:10.1256/smsqj.53106.

Erying, V., T. Shepherd, and D. Waugh (Eds.) (2010), SPARC report on the evaluation of chemistry-climate models, SPARC Rep. 5, World Clim. Res. Programme, Geneva, Switzerland.

Fueglistaler, S., M. Bonazzola, P. H. Haynes, and T. Peter (2005), Stratospheric water vapor predicted from the Lagrangian temperature history of air entering the stratosphere in the tropics, J. Geophys. Res., 110, D08107, doi:10.1029/2004JD005516.

Hossaini, R., M. P. Chipperfield, B. M. Monge-Sanz, N. A. D. Richards, E. Atlas, and D. R. Blake (2010), Bromoform and dibromomethane in the tropics: A 3-D model study of chemistry and transport, Atmos. Chem. Phys., 10(2), 719-735, doi:10.5194/acp-10-719-2010.
Hossaini, R., M. P. Chipperfield, W. Feng, T. J. Breider, E. Atlas, S. A. Montzka, B. R. Miller, F. Moore, and J. Elkins (2012), The contribution of natural and anthropogenic very short-lived species to stratospheric bromine, Atmos. Chem. Phys., 12(1), 371-380, doi:10.5194/acp-12371-2012.

Martin, G. M., et al. (2011), The HadGEM2 family of Met Office Unified Model climate configurations, Geosci. Model Dev., 4(3), 723-757, doi:10.5194/gmd-4-723-2011.

Montzka, S. A., J. H. Butler, B. D. Hall, D. J. Mondeel, and J. W. Elkins (2003), A decline in tropospheric organic bromine, Geophys. Res. Lett., 30(15), 1826, doi:10.1029/2003GL017745.

Montzka, S., et al. (2011), Ozone-depleting substances (ODSs) and related chemicals, in Scientific Assessment of Ozone Depletion: 2010, Rep. 52, chap. 1, pp. 1-112, Global Ozone Res. and Monit. Proj., World Meteorol. Organ., Geneva, Switzerland.

Morgenstern, O., P. Braesicke, F. M. O’Connor, A. C. Bushell, C. E. Johnson, S. M. Osprey, and J. A. Pyle (2009), Evaluation of the new UKCA climate-composition model-Part 1: The stratosphere, Geosci. Model Dev., 2(1), 43-57, doi:10.5194/gmd-2-43-2009.

Ordóñez, C., J.-F. Lamarque, S. Tilmes, D. E. Kinnison, E. L. Atlas, D. R. Blake, G. S. Santos, G. Brasseur, and A. Saiz-Lopez (2012), Bromine and iodine chemistry in a global chemistry-climate model: Description and evaluation of very short-lived oceanic sources, Atmos. Chem. Phys. 12(3), 1423-1447, doi:10.5194/acp-12-1423-2012.

Pyle, J. A., N. Warwick, X. Yang, P. J. Young, and G. Zeng (2007), Climate/ chemistry feedbacks and biogenic emissions, Philos. Trans. R. Soc. A, 365(1856), 1727-1740, doi:10.1098/rsta.2007.2041.

Quack, B., and D. Wallace (2003), Air-sea flux of bromoform: Controls, rates, and implications, Global Biogeochem. Cycles, 17(1), 1023, doi:10.1029/ 2002 GB001890.

Rayner, N. A., D. E. Parker, E. B. Horton, C. K. Folland, L. V. Alexander, D. P. Rowell, E. C. Kent, and A. Kaplan (2003), Global analyses of sea surface temperature, sea ice, and night marine air temperature since the late nineteenth century, J. Geophys. Res., 108(D14), 4407, doi:10.1029/ 2002JD002670.

Salawitch, R. J., D. K. Weisenstein, L. J. Kovalenko, C. E. Sioris, P. O. Wennberg, K. Chance, M. K. W. Ko, and C. A. McLinden (2005), Sensitivity of ozone to bromine in the lower stratosphere, Geophys. Res. Lett., 32, L05811, doi:10.1029/2004GL021504.

Sinnhuber, B. M., N. Sheode, M. Sinnhuber, M. P. Chipperfield, and W. Feng (2009), The contribution of anthropogenic bromine emissions to past stratospheric ozone trends: A modelling study, Atmos. Chem. Phys., 9(8), 2863-2871.

Stevenson, D., R. Doherty, M. Sanderson, C. Johnson, B. Collins, and D. Derwent (2005), Impacts of climate change and variability on tropospheric ozone and its precursors, Faraday Discuss., 130, 41-57, doi:10.1039/b417412g.

Sturges, W., D. Oram, L. Carpenter, S. Penkett, and A. Engel (2000), Bromoform as a source of stratospheric bromine, Geophys. Res. Lett., 27(14), 2081-2084, doi:10.1029/2000GL011444.

van Vuuren, D. P., et al. (2011), The representative concentration pathways: An overview, Clim. Change, 109(1-2), 5-31, doi:10.1007/s10584-0110148-z.

Wofsy, S., M. McElroy, and Y. Yung (1975), Chemistry of atmospheric bromine, Geophys. Res. Lett., 2(6), 215-218, doi:10.1029/GL002i006p00215.

Wuebbles, D., K. Grant, P. Connell, and J. Penner (1989), The role of atmospheric chemistry in climate change, J. Air Waste Manage. Assoc., 39(1), 22-28.

Zeng, G., J. A. Pyle, and P. J. Young (2008), Impact of climate change on tropospheric ozone and its global budgets, Atmos. Chem. Phys., 8(2), 369-387. 